\title{
Approaches to Operations Accounting Regarding Mortgage of the Enterprise as a Property Complex
}

\author{
Kulikova L.I.a \\ Sokolov A.Y. b \\ Ivanovskaya A.V.c \\ Akhmedzyanova F.N. ${ }^{d}$ \\ a bcd Kazan Federal University, Institute of Management, Economics and Finance, Kazan, 420008, Russia \\ Emails: anna_ivanovski@mail.ru
}

\section{Doi:10.5901/mjss.2015.v6n1s3p411}

\section{Abstract}

The present paper offers two options for organization of separate accounting transactions related to property complex referred to a mortgage. The first option involves separation of "Mortgaged enterprise" analytical accounts additional to the accounts of the property assets and liabilities of the mortgaged property complex. The second option provides for separation of all transactions with the mortgaged property complex to a special balance. Each of these offered approaches has its own scope of application and ensures the formation of operational information on the balance value of the mortgaged property complex, which is necessary for the purposes of monitoring of compliance with the terms of the mortgage agreement and disclosures in the financial statements.

Keywords: mortgage, accounting, property complex, IFRS 8, separate balance sheet

\section{Introduction}

The organization can possess more than one enterprises included into a property complex. It all depends on how many independent activities the organization in question carries out. For example, it can simultaneously hold several hotels, restaurants or shops. Each of these objects individually may be the subject of the mortgage agreement as well as other contracts. Upon the sale of the enterprise as a property complex its owner is changed, thus the seller may continue carrying out his business activity as he possesses a monetary amount received for the sale.

Currently the property complexes mortgaging in Russia is not as widespread as a of individual property objects. This is largely explained by a more complex evaluation and registration procedures of such collateral. However, according to the information from public sources, a variety of property complexes may serve as mortgaged subjects: enterprise for packing and storage of fertilizers, soft drinks plant, canning plant, paper and cardboard plant, bakery plant, poultry processing plant, glass manufacturing plant, dairy factory, fish processing complex, enterprise for the ropes production, gas filling stations, etc. The development of the attitude to the enterprise as to a property complex in the conditions of the mortgage loan requires the research of the problems concerning the transactions reflecting in the accounting and reporting.

The aim of this study is to develop the approaches to the accounting of the mortgage operations of the enterprise as a property complex, allowing the information arrangement in the accounting of the mortgaged property complex value.

\section{Method}

Under the Russian legislation, the mortgage of the enterprise as a property complex includes all tangible and intangible assets related to this enterprise, including buildings, structures, equipment, inventory, raw materials, finished products, exclusive rights, as well as financial assets. In this case the right to pledge applies to all the property, which is a part of the pledged enterprise, including the one acquired within the period of the mortgage, unless otherwise has been provided by the law or the contract. The contract may also stipulate the mortgage spread to the products and revenues resulting from the use of the mortgaged property. 
The property of the enterprise is defined as the difference between its assets and debts [1]. Therefore, under the mortgage of the enterprise conditions there appears such quite an extraordinary phenomenon as the mortgage of the debt. The debt issue solution is very important. The mortgagee is not interested in the inclusion of all debts in the pledged enterprise, as it may entail a significant reduction of its purchase price in the event of its possible sale. At the same time, separation of all debts from the enterprise is not in the interest of the mortgagor, as he may be not able to start a new activity [2]. In our opinion, the mortgagor can afford not to include the debts into the mortgaged enterprise only in case there are some additional sources allowing to cover the said debts, other than the revenues received from the activities of the pledged subject. If there are no other means to cover a debt, then the liabilities associated with the activities of the property complex shall be included into the mortgaged enterprise. Of course, this will reduce the net asset value of the property complex and consequently lead to the lower cost of the enterprise. But under these conditions, the mortgagor will actually be able to maintain the value of the mortgaged enterprise at the appropriate level, which is one of the basic conditions in the enterprise mortgage as a property complex.

In view that the mortgaged property complex has such a complicated structure, it is important to evaluate it properly and organize a proper accounting.

The mortgagee and the mortgagor reflect the amount of the received and issued collateral in the assessment offbalance indicated in the mortgage contract of the enterprise and disclose in the notes to the financial statements [3]. As with any other mortgage assets, it is appropriate to account separately the collateralized financial assets and liabilities [4].

In terms of completeness and reliability of accounting information, we deem it necessary to organize a separate accounting of assets and liabilities included in the mortgaged enterprise, as well as gains and losses resulting from its activities.

Separate accounting of all transactions carried out in the framework of the activities of the mortgage subject (the enterprise) is especially necessary if the mortgagor fulfills its activity in several directions. One of the conditions relating to the mortgage of the enterprise is to prevent the mortgagor from reduction of the enterprise cost. Competently organized separate accounting of operations related to the mortgaged enterprise will allow getting of operating data regarding the carrying value of the enterprise and control the mortgage agreement execution.

\section{Result}

Problems of mortgage operations reflecting in the accounting are revealed in the works of Masood, $\mathrm{O}$. and M. Bellalah [5], Huizinga, H. and L. Laeven [6], Weiss, N.E. [7], Freeman, W., Wells, P. and A. Wyatt [8].

Herewith, the research works on accounting do not pay much attention to the peculiarities of accounting operations arrangement at the mortgage of the enterprise as a property complex. We offer two options of separate accounting for the mortgaged enterprise and operations with it:

1) opening of the subaccounts "Mortgaged enterprise" to all accounts of property, liabilities, income, expenditures and capital, which reflect operations within the scope of the mortgaged enterprise operations;

2) separation of the mortgaged enterprise on a separate balance sheet (Fig. 1).

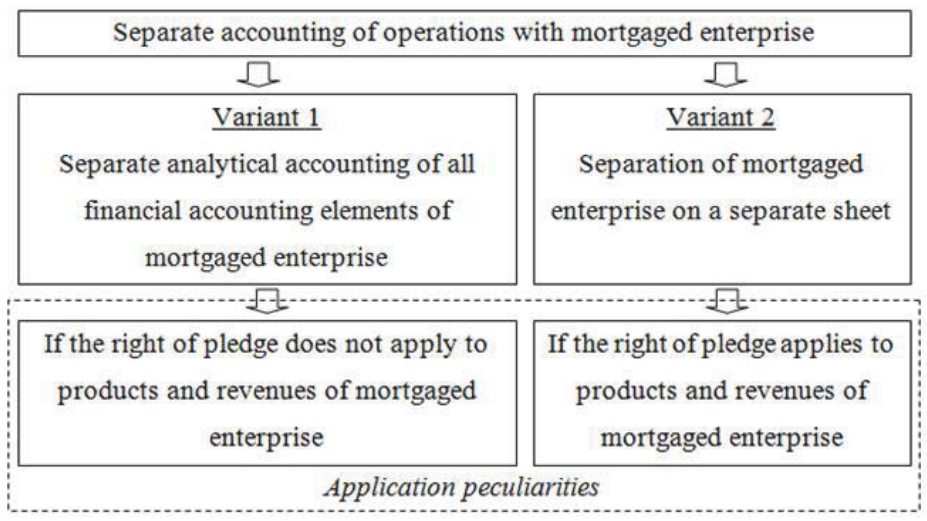

Fig. 1. Variants of separate accounting of operations with the mortgaged property complex

Each option has its advantages and disadvantages. In case the mortgage contract clearly defines the property included in the mortgaged enterprise (for example, shop building, production line, supply of materials and finished products of the 
definite manufacturing process), and the right of pledge does not apply to products and revenues of the enterprise activity, it will be more reasonable to open special sub-accounts to the ones accounting the relevant property. Automation of the accounting process makes it possible to quickly generate an analytical report "Mortgaged enterprise" for monitoring of the conservation value of the mortgaged enterprise.

However, if the right of pledge applies to products and revenues brought by the enterprise, this option of separate accounting organization becomes practically unacceptable because of its complexity. In this case, it is advisable to separate assets and liabilities related to the mortgaged enterprise on a separate sheet, although there will be no legal separation of the enterprise unit in this situation. We recommend to fulfill the transfer of the property and liabilities of the mortgaged enterprise to a separate balance sheet via the account "Internal organizational settlements"; this should be made by a separate subaccount 1 "Settlements on the property and liabilities of the mortgaged enterprise".

All operations directly related to the activities of the mortgaged enterprise within the period of the mortgage contract validity must be reported on a separate sheet with the identification of the financial result of the enterprise's activities. Upon termination of the mortgage, the assets, liabilities and financial results of the enterprise should be transferred into the principal balance of the legal entity.

In our opinion, when reflecting operations of the mortgaged property complex on a separate balance sheet and identifying the cost of products and revenues of the enterprise (financial result), part of the total expenses of the legal entity should be transferred to a separate balance sheet, otherwise the financial result of the property complex identified on the isolated sheet will be unreliable. For these purposes, a Subaccount 2"Settlements of common expenses compensation" should be opened to the "Internal organizational settlements" account.

If a mortgage agreement of the enterprise as a property complex stipulates, that the mortgagee has the right to a pledge on the products and revenues brought by the enterprise, there may occur an ambiguous situation: perhaps, the debtor-mortgagor has expected to repay the liabilities by the mortgage loan in full or in part due to the profit brought by this property complex; however he will not be able to administer the profit for these purposes, as it is not directly related to production activities of the mortgaged enterprise. Therefore, in our opinion, there should be a condition stipulated by the contract of mortgage determining the part of the profits from the activities of the mortgaged property complex, which the debtor-mortgagor shall have the right to transfer on repayment of the mortgage loan and the interest thereon. The debt on mortgage liabilities shall be recorded on the main balance sheet. We offer to reflect the transfer of part of the mortgaged enterprise profits for repayment of mortgage liabilities using Subaccount 3 "Settlements of the mortgage loan repayment" to the Account "Internal organizational settlements".

The general scheme of operations on a separate balance sheet using the account "Internal Settlements" is represented in Figure 2. Accounting records on the primary balance will be reversed.

The debt formed on the account "Internal Settlements" by the sub-accounts 2 "Settlement of common expenses compensation" and 3 "Settlements of the mortgage loan repayment" shall be treated as the current debt and subject to repayment in cash.

Arrears on the account "Internal Settlements" by the subaccount "Settlements by the property and liabilities of the mortgaged enterprise" shall be treated as a capital of the mortgaged enterprise.

For separation of the cash flows by the enterprise activity of the mortgaged enterprise and other activities of the mortgagor we recommend opening a separate settlement account for the operations of the mortgaged enterprise.

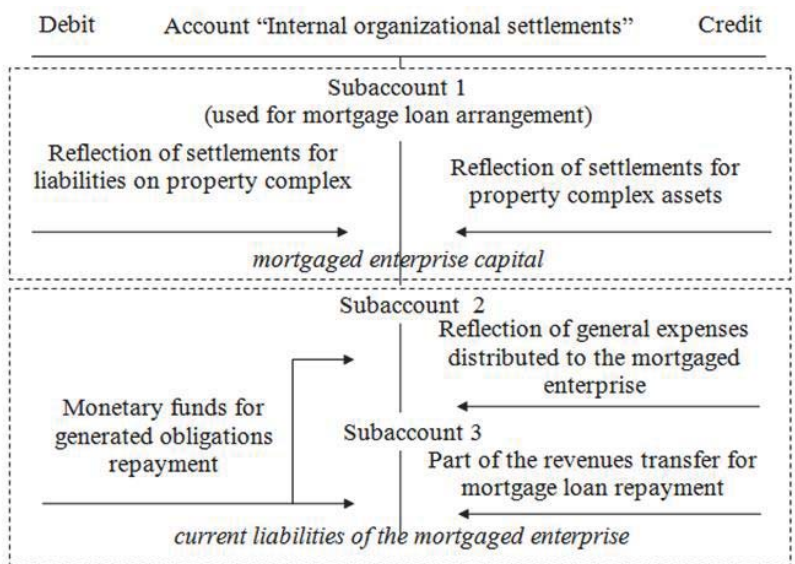

Fig. 2. Recommended flow process chart for a separate balance sheet using the account "Internal Settlements" 
The following items will help to ensure the reliability of balance sheet valuation of mortgaged property complex:

- accounting of fixed assets under the revaluation model;

- inventory verification for impairment;

- $\quad$ inventory of receivables and payables and timely formation of reserves for doubtful debts $[9,10]$.

Whereas the last two paragraphs should be carried out by the organization in any case, the revaluation of fixed assets is not required under the International Financial Reporting Standards [11]. If the accounting policy of the organization does not provide for the revaluation of fixed assets, then, in our view, the revaluation surplus or devaluation of fixed assets can be reflected only in the statement of the pledged enterprise value.

The current value report of the pledged enterprise can be made basing on the analytical accounting data (under the Approach I) or on a separate balance of the mortgaged enterprise (the Approach II). We recommend the following form of such report presented in Table 1.

Table 1. Report on the mortgaged enterprise value

\begin{tabular}{|l|c|}
\hline Indexes & Amount, thous.rub. \\
\hline 1. Total assets of the enterprise & 12948 \\
\hline including & 11200 \\
\hline Fixed assets & 1100 \\
\hline Reserves & 400 \\
\hline Trade receivables & 1 \\
\hline Other receivables & 247 \\
\hline Monetary funds & 718 \\
\hline 2. Total liabilities of the enterprise & \\
\hline including & 70 \\
\hline Current internal settlements & 400 \\
\hline Trade payables & 170 \\
\hline Arrears of wages & 78 \\
\hline Debt to the budget and extra budgetary funds & 12230 \\
\hline 3. Balance sheet value of the enterprise & 1300 \\
\hline 4. The amount of revaluation surplus(+) (markdown(-)) of fixed assets & 13530 \\
\hline 5. Total actual cost of the enterprise & \\
\hline
\end{tabular}

According to the data in the Table 1, the balance (BVE) and the real (RVE) value of the mortgaged enterprise are determined by the formulas:

$B V E=A-L$,

RVE = BVE +l-R,

where $A$ - is the total assets of the mortgaged enterprise,

$L-$ is the total liabilities of the mortgaged enterprise,

$\mathrm{R}$ - revaluation surplus (+) or write-downs (-) of the fixed assets of the mortgaged enterprise.

It should be noted that, under the conditions of continuity of the mortgaged enterprise activity, all the assets and liabilities recorded on a separate sheet are accounted to determine its balance sheet value, as they are inextricably linked to the fulfillment of the main activity at the enterprise $[12,13]$. In case of failure on the part of the debtor to pay off the mortgage liabilities and foreclosure on the mortgaged property, valuation of the enterprise should be carried out somewhat differently according to the data on the individual balance: such items of the assets and liabilities, which relate solely to the activity of the legal person - mortgager, should not be accounted, and cannot be transferred to the new owner of the property complex by sale.

\section{Conclusion}

Our proposed options for separate accounting of operations with the pledged property complex will allow quick generating of information about the value of the mortgaged enterprise. This is necessary both for the fulfillment of the mortgage contract conditions monitoring, and for disclosing of information about the mortgaged enterprise in the financial statements. 
Mortgaged enterprise can be represented in the financial statements as a reportable segment of the mortgaging organization, as the risks associated with its activities differ significantly from the risks from other activities of the mortgagor. In this respect, in addition to the compliance with the disclosure requirements of the reportable segments as provided by IFRS 8 "Operating segments", it is advisable to disclose the following information in the notes to the financial statements regarding the segment "Mortgaged enterprise":

- $\quad$ the term of the mortgage agreement of the enterprise;

- the amount of mortgage liabilities;

- a report on the mortgaged enterprise value at the beginning and in the end of the reporting period in the form shown in Table 1;

- forecasts for the execution of the mortgage obligation.

\section{References}

Chung, Y.P., Na, H.S., Smith, R. How important is capital structure policy to firm survival? // Journal of Corporate Finance 22 (1), 2013. pp. 83-103.

Raberto, M., Teglio, A., Cincotti, S. 2012. Debt, deleveraging and business cycles: An agent-based perspective // Economics. Volume 6: http://www.economics-ejournal.org/economics/journalarticles/2012-27/version_1/count.

Kulikova, L.I., Goshunova, A.V. Measuring efficiency of professional football club in contemporary researches // World Applied Sciences Journal 25 (2), 2013. pp. 247-257.

Vetoshkina E.Yu., Tukhvatullin R.Sh. The problem of accounting for the costs incurred after the initial recognition of an intangible asset // Mediterranean Journal of Social Sciences 5 (24), 2014. pp. 52-55.

Masood, O., Bellalah, M. Role of accountants and fair value accounting leading towards the global financial crisis // International Journal of Business 19 (3), 2014. pp. 237-254.

Huizinga, H., Laeven, L. Bank valuation and accounting discretion during a financial crisis // Journal of Financial Economics 106 (3), 2012. pp. 614-634.

Weiss, N.E. Commercial and residential mortgages // Mortgages: Policies, Proposals and Trends. Nova Science Publishers, Inc., 2012. pp. 119-134.

Freeman, W., Wells, P., Wyatt, A. Insights from the failure of the Countrywide Financial Corporation // International Journal of Managerial Finance 10 (1), 2014. pp. 115-136.

Talnagiova, V., Cerna, L. Measurement of assets in financial statements of an industrial company // Annals of DAAAM and Proceedings of the International DAAAM Symposium, 2011. pp. 1161-1162.

Aletkin P.A. International Financial Reporting Standards Implementation into the Russian Accounting System // Mediterranean Journal of Social Sciences 5 (24), 2014. pp. 33-37.

Missonier-Piera, F. Motives for fixed-asset revaluation: An empirical analysis with Swiss data // International Journal of Accounting 42 (2), 2007. pp. 186-205.

Azmitov R.R., Ivanovskiy I.A., Korabelnikova L.L. Features of Russian Companies Real Estate Appraisal in the Accounting System /I Mediterranean Journal of Social Sciences 5 (24), 2014. pp. 242-245.

Devaney, M., Weber, W.L. Efficiency, scale economies, and the risk/return performance of real estate investment trusts // Journal of Real Estate Finance and Economics 31 (3), 2005. pp. 301-317. 